various conservation strategies if, for example, drier weather is expected.

"For years, we've done this by ourselves, just trying to balance all of this in our heads," says Jim Porter, who heads water operations for the city's department of environmental protection. "Hopefully, we can predict out a little further into the future."

The potential savings are enormous. Coping with the silt problem by building a new intake system at one reservoir or increasing the size of a second reservoir would cost between US\$200 million and $\$ 500$ million. A new filtration plant could run to more than $\$ 10$ billion. By contrast, the city's analysis suggests that an integrated reservoir-management system can tackle the problem for roughly $\$ 8$ million.

But to make it happen, the city first needs better streamflow forecasts. Although the National Weather Service makes streamflow predictions, it has until now done so mainly by comparing current conditions - precipitation, soil moisture, snowpack and streamflow - with historical averages, and then extrapolating the results. This approach assumes that streamflows will evolve as they have in the past under similar circumstances, but does not look ahead to future conditions.

The incoming system - years in the making - combines short-term and seasonal precipitation forecasts, and adds those predictions into the streamflow forecasts. To validate the system, the National Weather Service checked its predictions against historical data.

New York is paying the Weather Service about \$1 million to accelerate the process so that the system will be available for use this year. "We now have something that is ready for prime time," says John Schaake, a hydrologist and independent consultant in Baltimore, Maryland, who helped to develop the streamflow-forecast system.

The system will be available at 5 of the 12 regional US river-forecast centres, although it is unclear when it will become standard nationally. There are budget constraints, and each centre will have to customize the system. "There's a lot of interest, but the question is how you institutionalize that," says Kevin Werner, a hydrologist at the Colorado Basin River Forecast Center in Salt Lake City, Utah.

And it is also unclear whether others will follow New York's lead and hitch the forecasts to a reservoir-management system. Demonstrating that the forecasts improve water management should help to ease doubts, says Daniel Sheer, president of HydroLogics Incorporated in Columbia, Maryland, which is providing New York with the reservoir-management software. "There will be much broader interest in the forecasts if we can show that they work." -
PUBLISHING

\section{Half of 2011 papers now free to read}

\section{Boost for advocates of open-access research articles.}

\section{BY RICHARD VAN NOORDEN}

$O^{\mathrm{e}}$ earch the Internet for any research article published in 2011, and you have a 50-50 chance of downloading it for free. This claim - made in a report ${ }^{1}$ produced for the European Commission - suggests that many more research papers are openly available online than was previously thought. The finding, released on 21 August, is heartening news for advocates of open access. But some experts are raising their eyebrows at the high numbers.

There has been a steady move over the past few years towards getting research papers that are funded by government money into the public domain, and the best estimates ${ }^{2,3}$ for the proportion of papers free online run at around

\section{FREEDOM ONLINE}

At least" $43 \%$ of research papers published during 2008-11 are now free online, but the proportion varies by country and discipline.

$$
\text { - Published in open-access journal }
$$
- Total free online ${ }^{\dagger}$

Discipline

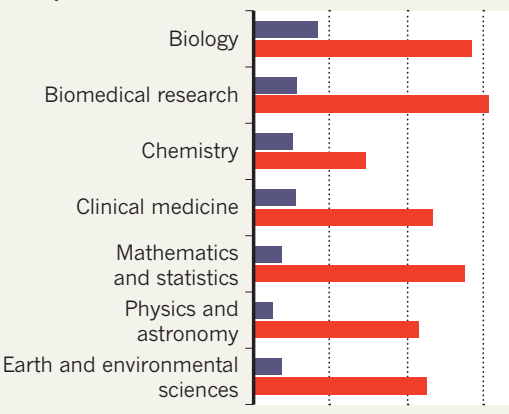

Country

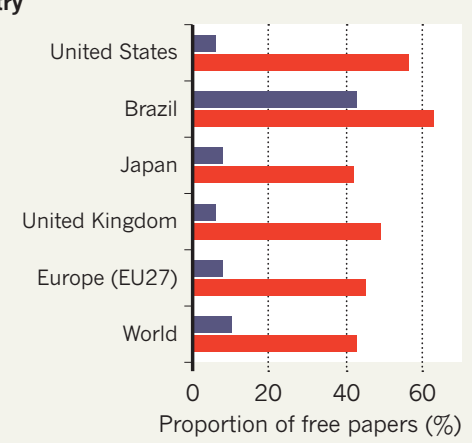

The true proportion is likely to approach $50 \%$, because automated software does not find every free paper. made free by subscription journals, as well as self-archived free papers.
$30 \%$. But these are underestimates, argues Éric Archambault, the founder and president of Science-Metrix, a consultancy in Montreal, Canada, that conducted the analysis for the European Commission.

The firm initially asked a team led by Stevan Harnad, an open-access campaigner and cognitive scientist at the University of Quebec in Montreal, to check a random sample of 20,000 papers published in 2008 (from the Scopus database of papers run by Elsevier). It used a program designed by Yassine Gargouri, a computer scientist at the same university, to find free articles. The team found that $32 \%$ of the papers that it downloaded in December 2012 were freely available. But when Archambault's group checked 500 of these papers manually using Google and other search engines and repositories, the figure rose to $48 \%$.

On the basis of this initial test, ScienceMetrix applied its own automated software, or 'harvester', to 320,000 papers downloaded from 2004 to 2011; the tool searches publishers' websites, institutional archives, repositories such as arXiv and PubMed Central, and sites such as the academic networking site ResearchGate and the search engine CiteSeer ${ }^{\mathrm{X}}$.

It found that an average of $43 \%$ of articles published during 2008-11 are available online for free, with the results varying by country and discipline (see 'Freedom online'). But the true figure is probably higher, because the harvester does not pick up every free paper. When the incompleteness is adjusted for, the proportion of free articles from 2011 rises to about $50 \%$, says Archambault.

The report "confirms my optimism", says Peter Suber, director of the Office for Scholarly Communication at Harvard University in Cambridge, Massachusetts, and a proponent of open access to research. He thinks that it reflects the experiences of working scientists today. "When researchers hit a paywall online, they turn to Google to search for free copies - and, increasingly, they are finding them," he says.

The rise of open-access journals is part of the explanation: the share of papers published in these journals rose from $4 \%$ in 2004 to $12 \%$ by 2011 , the report found — agreeing with figures published last year by Bo-Christer Björk, who

\section{$\rightarrow$ NATURE.COM}

For more on open-access publishing, visit: go.nature.com/gdtvaw 
studies information systems at the Hanken School of Economics in Helsinki.

But the number of peer-reviewed manuscripts made free by other means has also increased, the report says. That includes those eventually made free - often a year after publication, and sometimes on a temporary promotional basis - by publishers that charge for subscription. But it also includes manuscripts that researchers themselves archive online on repositories and personal websites. Some of the articles, although free to read, may not meet formal definitions of open access because, for example, they do not include details on whether readers can freely reuse the material.

The report does not try to distinguish between types of manuscript, nor where and how they were posted, says Archambault. "The situation is so complex that it's very hard to measure."

Björk says that the latest measurements seem to have been carefully done, although he adds that because he does not have details of the robotic harvester's code, he cannot evaluate its method. "Experts on the subject would probably agree that the open-access share of papers, measured around a year and a half after publication, is currently at least 30\%," he says. "Anything above that is dependent on ways of measuring, with this new study representing the highest estimate."

The report, which was not peer reviewed, calls the 50\% figure for 2011 a "tipping point", a rhetorical flourish that Suber is not sure is justified. "The real tipping point is not a number, but whether scientists make open access a habit," he says.

Harnad thinks that the next step should be to obtain more accurate measures of when papers become free. "It's hardly a triumph if articles are only accessible after a one-year embargo," he says. Greater measurement accuracy is tricky to achieve, he adds, because Google routinely blocks all robotic harvesters. He believes that research on the growth of open access should be given special concessions.

The proportion of free online papers is likely to increase in the next few years. The European Commission says that, from 2014, the results of all research funded by the European Union must be open access. And in February, the US White House announced that government-funded research should be made free to read within 12 months of publication (see Nature 494, 414-415; 2013). Federal agencies are due to submit their plans for achieving this to the US Office of Science and Technology Policy by 22 August.

1. Archambault, E. et al. Proportion of Open Access Peer-Reviewed Papers at the European and World Levels - 2004-2011 (Science-Metrix, 2013).

2. Laakso, M. \& Björk, B.-C. BMC Med. 10, 124 (2012).

3. Björk, B.-C., Laakso, M., Welling, P. \& Paetau, P. J. Am. Soc. Inf. Sci. Technol. (in the press).

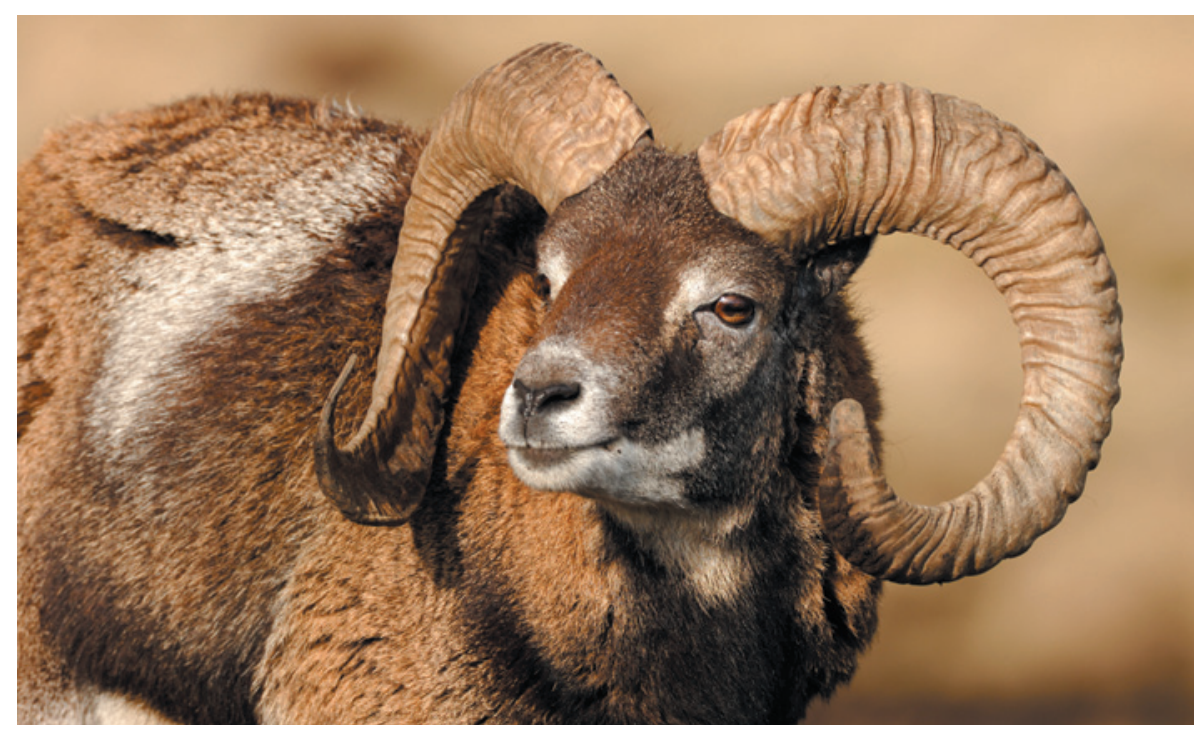

Soay sheep have greatest sexual fitness when they have two versions of a gene that determines horn size.

\section{EVOLUTIONARY GENETICS}

\section{Big horns clash with longevity in sheep}

\section{Gene for small horns lowers sexual fitness but boosts lifespan.}

\section{BY EWEN CALLAWAY}

A lpha Red 78 - a ram with horns like elephant tusks - sired 95 lambs before he died at the ripe (for a ram) old age of nine. A gene with a role in horn growth explains his fertility and his longevity, finds a study of sheep on a remote Scottish isle. The work also explains how variation can persist in traits that offer big reproductive boosts.

Ample horns are a ram's ticket to reproductive success. During the breeding season, males fight for access to females, and those with the largest horns win. But if big horns are a sexual asset, the genes underlying the trait should have become ubiquitous, says Susan Johnston, an evolutionary biologist at the University of Edinburgh, UK, who led the research. Yet some male sheep have short horns or none at all. "From an evolutionary perspective, it doesn't really make sense," Johnston says.

Johnston's team turned to the sheep living on Hirta, an island 160 kilometres west of the Scottish mainland. The animals, a primitive breed called Soay (Ovis aries), are known for their diminutive size and their agility on cliffs.

Two years ago, Johnston's group reported that a single gene, RXFP2, explains horn variability in the sheep (S. E. Johnston et al. Mol. Ecol. 20, 2555-2566; 2011). One version of the gene, $\mathrm{Ho}^{+}$, is linked to large horns; another allele, $\mathrm{Ho}^{P}$, is associated with small ones.
In the latest study, published in Nature, Johnston's team related the RXFP2 genes of 1,750 sheep to three factors: horn size, reproductive success and lifespan (S. E. Johnston et al. Nature http://dx.doi.org/10.1038/ nature $12489 ; 2013)$. Males with one or two copies of the $\mathrm{Ho}^{+}$allele had the biggest horns. They fathered twice as many lambs as those with two copies of the short-horned allele, averaging 3 (versus 1.6) each year, says Johnston. But where lifespan was concerned, rams with two copies of $\mathrm{Ho}^{P}$ had an edge, she says, with a $75 \%$ chance per year of surviving the harsh Hirta winter, compared with a $61 \%$ chance for those with two long-horned alleles.

The scientists found that rams with one version of each allele (heterozygotes) had the best of everything: they were big-horned, fecund and long-lived. And this explains why shorthorned rams persist. "I'm just impressed by the simple elegance of this story," says Hopi Hoekstra, an evolutionary geneticist at Harvard University in Cambridge, Massachusetts.

Johnston says that to learn more, scientists will need to study the gene: in humans and mice, it is involved in sexual development and bone density. She adds that heterozygotes such as Alpha Red 78 end up with more offspring largely because they outlive homozygous bighorned males, which tend to die young.

The ram probably wasn't winning on his looks. "He was quite an ugly sheep," she says. 